\title{
Protective effects of triple fermented barley extract (FBe) on indomethacin-induced gastric mucosal damage in rats
}

Jong-Min Lim', Chang-Hyun Song ${ }^{2,3}$, Su-Jin Park²,3, Dong-Chan Park', Go-Woon Jung ${ }^{1}$, Hyung-Rae Cho', Khawaja Muhammad Imran Bashir ${ }^{4,5}$, Sae Kwang Ku ${ }^{2^{*+}}$ and Jae-Suk Choi ${ }^{5,6^{*}+}$ (D)

\begin{abstract}
Background: Hordeum vulgare L (barley) contains numerous phenolic substances with proven anticancer, antioxidant and gastroprotective activities. Saccharification increases the functionality and bioavailability of these compounds thus can aid in the development of a natural product based medicine. This study aimed to investigate the possible gastroprotective effects of saccharification on the indomethacin (IND)-induced gastric ulcers in rats using Weissella cibaria- and Saccharomyces cerevisiae-triple fermented H. vulgare extract (FBe).

Methods: In total, 60 healthy male 6-week old Sprague-Dawley SD (SPF/NAF Outbred CrljOri:CD1) rats were commercially purchased. The FBe extract $\left(100,200\right.$, and $300 \mathrm{mg} \mathrm{kg}^{-1}$ ) was orally administered $30 \mathrm{~min}$ before an oral treatment of IND $\left(25 \mathrm{mg} \mathrm{kg}^{-1}\right)$. Six hours after IND treatment, variations in the histopathology, myeloperoxidase (MPO) activity, gross lesion scores, lipid peroxidation, and antioxidant defense system component (superoxide dismutase $(\mathrm{SOD})$, catalase (CAT), and glutathione (GSH)) levels were measured.

Results: FBe treatment showed significant $(p<0.01$ or $p<0.05)$ and dose-dependent decrease in gastric mucosal damage. In the present study hemorrhagic gross lesions, gastric MPO activity, and histopathological gastric ulcerative lesions were observed in IND-treated rats compared to the IND control rats. In particular, FBe, in a dose-dependent manner, strengthened the antioxidant defense systems, decreased lipid peroxidation and CAT activity by increasing the GSH levels and SOD activity, respectively. The $200 \mathrm{mg} \mathrm{kg}^{-1}$ dose of FBe was similarly gastroprotective as the $10 \mathrm{mg} \mathrm{kg}^{-1}$ dose of omeprazole in rats with IND-induced gastric mucosal damage.

Conclusions: The findings of the present study show that an oral administration of FBe had positive gastroprotective effects through strengthening the body antioxidant defense system and anti-inflammatory effects.
\end{abstract}

Keywords: Barley extract, Fermentation, Gastric ulcer, Gastroprotection, Hordeum vulgare, Indomethacin

\section{Background}

Occurrence of gastric ulcer has been associated with numerous factors such as imbalance between protective and aggressive factors, pulmonary and liver diseases, alcohol consumption, and non-steroidal and steroidal

\footnotetext{
* Correspondence: gucci200@hanmail.net; jsc1008@silla.ac.kr

'SK Ku and J-S Choi contributed equally to this work.

2Department of Anatomy and Histology, College of Korean Medicine, Daegu Haany University, 290 Yugok-dong, Gyeongsan-si, Gyeongsanbuk-do 38610, Republic of Korea

${ }^{5}$ Research Center for Life Science Technologies in Medicine and Environment, 31, Gwahaksandan 1-ro, 60 beon-gil, Gangseo-gu, Busan 46742, Republic of Korea

Full list of author information is available at the end of the article
}

drugs [1, 2]. Due to favorable preventive effects in instances of malignant tumors, eclampsia, dementia, and hyperlipidemia, the demand for non-steroidal anti-inflammatory drugs (NSAIDs) has remarkably increased in recent years [3]. However, NSAIDs have also been linked with risks of adverse gastrointestinal disorders including gastric mucosal ulceration, erosion, bleeding, and perforation [4]. About 25\% of urgent gastric ulcers have been related to NSAIDs administration [5], with various factors like stress and Helicobacter pylori infections exacerbating the condition related to gastric ulcers [6].

(c) The Author(s). 2019 Open Access This article is distributed under the terms of the Creative Commons Attribution 4.0 International License (http://creativecommons.org/licenses/by/4.0/), which permits unrestricted use, distribution, and reproduction in any medium, provided you give appropriate credit to the original author(s) and the source, provide a link to the Creative Commons license, and indicate if changes were made. The Creative Commons Public Domain Dedication waiver (http://creativecommons.org/publicdomain/zero/1.0/) applies to the data made available in this article, unless otherwise stated. 
Various synthetic anti-ulcer drugs such as misoprostol are used to cure NSAID induced gastric ulcers. Similarly, indomethacin (IND) is widely approved in medical practice as being an NSAID; it shows exceptional efficiency in the treatment of fever, pain and inflammation by suppressing the synthesis of prostaglandins through inhibiting the cyclooxygenase enzymes [7]. However, NSAIDs such as IND administration result in gastrointestinal tract infections due to the inhibition of prostaglandin synthesis [8]. In addition, IND generates harmful reactive oxygen species (ROS) involved in pathogenesis of gastric ulcers [9]. Apparently, the free radical scavenging property of synthetic drugs might have a protecting effect against gastric mucosal oxidative damage that accelerates healing of gastric ulcers [10]. However, disorder of gastric mucosal antioxidant defense system has also been associated with NSAIDs [11].

Investigating dietary plants that are valued in traditional medicine might hold promise for prolonged use. Functional foods originating from natural sources are gaining significance in the pharmaceutical industry. Fermented herb extracts have been widely used as a source of bioactive compounds in pharmaceutical and food industries as bioactivity of natural herbs increases during fermentation through biotransformation or probiotic effect [12-14]. Fermented barley extracts have revealed effective pharmacological effects including antioxidant [15], anti-atopic dermatitis [16], uric acid lowering [17], hepatoprotective [15], and immunostimulatory [18] activities. Potent anti-ulcer agents from natural herbs with strong antioxidant effects, such as Artemisia asiatica extract (Stillen ${ }^{\mathrm{TM}}$, Dong-A Pharmaceuticals, Yongin, Rep. of Korea) have also appeared in the market [19].

It is noted that fermented barley extract shows potent antioxidant potential in various in vivo models [20,21], and indomethacin induces gastric ulcer in SpragueDawley animal models $[6,10]$. This gained our attention to address the possible protective effect of fermented barley against IND-induced gastric ulcers in Sprague-Dawley rat model. Previously, we reported triple fermentation of barley using saccharification with Weissella and Saccharomyces as an effective and valuable fermentation choice [22-24] with less toxicity [25], and the present research intended to estimate the healing effect of triple fermented barley extract (FBe) on the IND-induced gastric ulcers in Sprague-Dawley rats, a representative valuable animal model to screen for gastroprotective agents $[6,10]$.

\section{Methods}

Experimental animals and husbandry

Sixty healthy male 6-week old Sprague-Dawley SD (SPF/

VAF Outbred CrljOri:CD1) rats purchased from
OrientBio Co., Seungnam, Republic of Korea, were used in this study following acclimatization for 10 days. Animals were raised in polycarbonate cages at $20-25^{\circ}$ $\mathrm{C}$ and a relative humidity of $30-35 \%$. The rats were subjected to 12-h photoperiod while food and water was freely accessible. With six groups and eight rats in each group, 48 rats were selected based on the body weight (average 258.58 $\pm 15.62 \mathrm{~g}$, ranged in 229.00-283.00 g) measured one day before test material administration and used for the experiments. Experimental groups (eight rats in each of the six groups) are presented in Fig. 1.

The animal experiments were conducted according to the international regulations of the usage and welfare of laboratory animals and were approved by the Institutional Animal Care and Use Committee, Daegu Haany University, Gyeongsan, Rep. of Korea [Approval No: DHU2014-087].

\section{Compositions of the fermented barley extract (FBe)}

Nutritional facts, including calories, carbohydrates, proteins, lipids, and dietary fiber levels were evaluated, according to the method of Food Code [26]. Total polyphenols and total flavonoids were evaluated according to the method of Health Functional Food Code [27].

\section{Preparations and administration of test materials}

The triple fermented barley extract (FBe) was provided by Glucan Corporation (Busan, Rep. of Korea). The FBe extract was prepared in three different steps. In saccharification (the first step), $1 \mathrm{~kg}$ non-glutinous barley was washed, soaked $(6 \mathrm{~h})$, drained (30 min), and steamed (15 min at $121^{\circ} \mathrm{C}$ ). After cooling, malt solution [ $10 \mathrm{~g}$ malt powder in $4 \mathrm{~L}$ distilled water] was added to the mixture and fermented for $12 \mathrm{~h}$ at $55^{\circ} \mathrm{C}$ in a $20 \mathrm{~L}$ glass bioreactor. In the second step, $20 \mathrm{~mL}$ suspension of Saccharomyces cerevisiae (ATCC, VA, USA) was added to the first fermentate, mixed thoroughly, and fermented again at $30{ }^{\circ} \mathrm{C}$ for $48 \mathrm{~h}$. In the last step, $20 \mathrm{~mL}$ of Weissella cibaria (lactic acid bacteria; KACC, Suwon, Rep. of Korea) was added to the second fermentate, mixed thoroughly, and fermented third time at $30{ }^{\circ} \mathrm{C}$ for $48 \mathrm{~h}$. The prepared third fermentate was sterilized $\left(150{ }^{\circ} \mathrm{C}\right.$ for $15 \mathrm{~min}$ ) and sieved through a 40-mesh sieve to get the final product (triple fermented barley extract; FBe). Some specimens of FBe [Code: FBe2014Ku01] were deposited in the herbarium of the Medical Research Center for Globalization of Herbal Formulation, Daegu Haany University, Gyeongsan, Rep. of Korea. The final product was stored at $4{ }^{\circ} \mathrm{C}$ to protect from moisture and light. FBe solutions (100, 200, and $300 \mathrm{mg} \mathrm{kg}^{-1}$ ) were prepared by dissolving in distilled water (DW) and orally administered once (in a volume of $5 \mathrm{~mL} \mathrm{~kg}^{-1}$ of rat) $30 \mathrm{~min}$ before IND ( $25 \mathrm{mg} \mathrm{kg}^{-1}$ in a volume of $5 \mathrm{~mL} \mathrm{~kg}^{-1}$ of rat) 


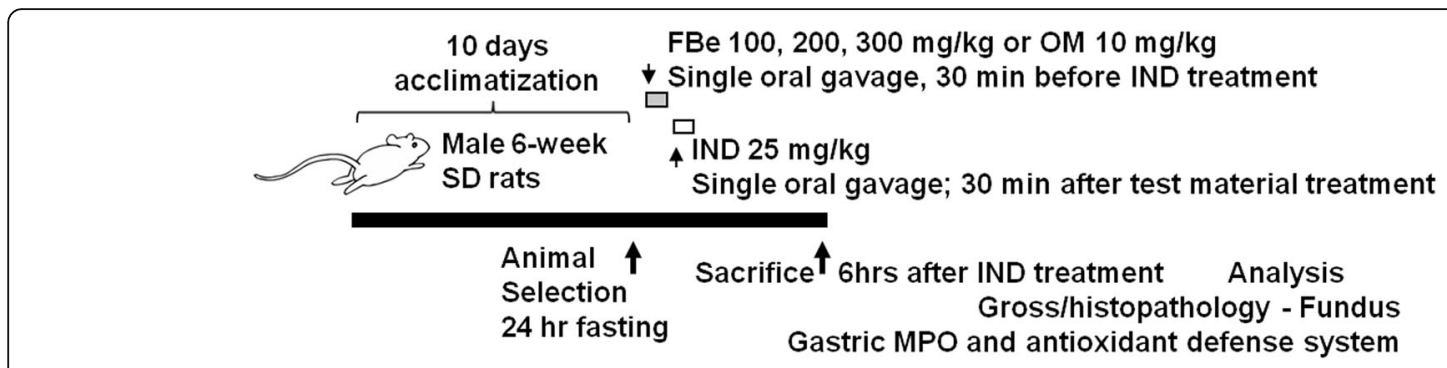

Fig. 1 Experimental designs used in this study. FBe: triple fermented barley extract as test material; IND: indomethacin; OM: omeprazole

administration. Omeprazole $\quad\left(10 \mathrm{mg} \mathrm{kg}^{-1}\right.$; OM; Sigma-Aldrich, St. Louis, MO, USA) was used as a reference drug [26]. To provide the similar experimental settings and administration stress, IND and intact control rats were once orally administered with $5 \mathrm{~mL} \mathrm{~kg}^{-1}(v / w)$ of DW instead of the test material (Fig. 1).

\section{Induction of gastric mucosal damages by IND in rats} Thirty minutes after administration of vehicle, dosages of FBe or OM on $24 \mathrm{~h}$ fasted rats, IND (Sigma-Aldrich) was single orally administered at a dosage of $25 \mathrm{mg} \mathrm{kg}^{-1}$ of rat [28]. In intact controls, only sterilized DW $(5 \mathrm{~mL}$ $\mathrm{kg}^{-1}$ ) was administered once by gastric gavages instead of IND (Fig. 1).

\section{Quantification of gross lesions}

The rats were sacrificed by cervical dislocation under anesthesia using $99.50 \% \mathrm{CO}_{2}$ gas $6 \mathrm{~h}$ after treatment with IND or vehicle. The stomach was excised after a median incision, fixed in $10 \%$ neutral buffered formalin for $24 \mathrm{~h}$, and acquired digital images. The ulcer areas on the stomach surface were estimated by an automated image analyzer (IMT i-solution Inc., Quebec, Canada) as reported by Suleyman et al. [28]. Gastric damage scores were calculated macroscopically by measuring the visible lesions.

\section{Determination of gastric myeloperoxidase contents}

A $0.2 \mathrm{~g}$ of the tissue sample was homogenized in $10 \mathrm{vol}-$ umes of ice-cold potassium phosphate buffer [50 mM $\mathrm{K}_{2} \mathrm{HPO}_{4}$, pH $6.0+0.5 \%$ hexadecyltrimethylammonium bromide (HETAB)], and centrifuged at $12,000 \times \mathrm{g}$ for 10 min at $4{ }^{\circ} \mathrm{C}$ [29]. Supernatant was discarded and the pellet was re-suspended in equal volumes of potassium phosphate buffer and $10 \mathrm{mM}$ EDTA. One unit of myeloperoxidase (MPO) activity was defined as the amount of MPO $\mathrm{g}^{-1}$ of tissue that changed an absorbance of 1.0 per min at $460 \mathrm{~nm}$ and $37^{\circ} \mathrm{C}$ [30].

\section{Determination of malondialdehyde (MDA) formation} Thiobarbituric acid method was used to determine the concentration of gastric mucosal lipid peroxidation [31].
The corpus mucosa of stomach was scraped and homogenized in $10 \mathrm{~mL}$ of $\mathrm{KCl}$ solution $\left(100 \mathrm{~g} \mathrm{~L}^{-1}\right)$. Five hundred microliter of the homogenate was added into a new tube containing thiobarbituric acid solution $[1.5 \mathrm{~mL}$ of 8 $\mathrm{g} \mathrm{L}^{-1}$ 2-thiobarbiturate (Sigma-Aldrich), $0.2 \mathrm{~mL}$ of $80 \mathrm{~g}$ $\mathrm{L}^{-1} \mathrm{SDS}, 1.5 \mathrm{~mL}$ of $200 \mathrm{~g} \mathrm{~L}^{-1}$ acetic acid, and $0.3 \mathrm{~mL}$ of DW], heated at $98^{\circ} \mathrm{C}$ for $1 \mathrm{~h}$, cooled at room temperature and added $5 \mathrm{~mL}$ of $\mathrm{n}$-butanol: pyridine (15:1; Sigma-Aldrich). The mixture was vortexed, centrifuged at $3000 \times \mathrm{g}$ for $30 \mathrm{~min}$, and measured the absorbance of the supernatant by UV/Vis spectrophotometer at $532 \mathrm{~nm}$. The 1,1,3,3-tetramethoxypropane (Sigma-Aldrich) was used to draw the standard curve and the results were displayed as $\mathrm{nM}$ of $\mathrm{MDA} \mathrm{g}^{-1}$ of wet tissue (nM/g tissue).

Estimation of gastric mucosal glutathione (GSH) content The GSH content was estimated by following a previously reported method of Sedlak and Lindsay [32]. The stomach's mucosal surface was homogenized in $2 \mathrm{~mL}$ of Tris- $\mathrm{HCl}$ buffer [ $50 \mathrm{mM}$ Tris $\mathrm{HCl}, 0.2 \mathrm{mM}$ sucrose, and $20 \mathrm{mM}$ EDTA; pH 7.5], precipitated with $0.1 \mathrm{~mL}$ of $25 \%$ trichloroacetic acid and centrifuged at $3500 \times \mathrm{g}$ for 40 $\min$ at $4{ }^{\circ} \mathrm{C}$ to remove the precipitate. The GSH content was determined in the supernatant using 2-nitrobenzoic acid (Sigma-Aldrich) by measuring the absorbance at $412 \mathrm{~nm}$ and the results were expressed as $\mathrm{nM} / \mathrm{mg}$ tissue.

\section{Tissue catalase (CAT) activity}

The CAT activity of tissue was calculated by following a previously reported study of Evans and Diplock [33]. Rat gastric mucosal homogenate was diluted with buffer as described before. The CAT dilution $(2 \mathrm{~mL})$ was mixed with $1 \mathrm{~mL}$ of $30 \mathrm{mM} \mathrm{H}_{2} \mathrm{O}_{2}$ and the absorbance was measured at $240 \mathrm{~nm}$. The CAT activity was expressed in $\mathrm{mM} / \mathrm{min} / \mathrm{mg}$ of tissue.

\section{Tissue superoxide dismutase (SOD) activity}

The SOD activity was examined by following the previously reported methods of Bashir et al. [34] with slight modifications. Briefly, gastric homogenate $(15 \mu \mathrm{l})$ was mixed with ethanol $(250 \mu \mathrm{l})$, chloroform $(125 \mu \mathrm{l})$, and 
cold deionized water $(450 \mu \mathrm{l})$. The homogenate mixture was then centrifuged at $8000 \times \mathrm{g}$ for $2 \mathrm{~min}$ at $4{ }^{\circ} \mathrm{C}$ and the extract $(500 \mu \mathrm{l})$ was added to the reaction mixture $[16 \%$ Triton X-100 $(100 \mu \mathrm{l}), 0.9 \mathrm{mM}$ nitroblue tetrazolium $(250 \mu \mathrm{l})$, and $500 \mu \mathrm{l}$ of $72.4 \mathrm{mM}$ triscacodylate buffer with $3.5 \mathrm{mM}$ diethylene pentaacetic acid ( $\mathrm{pH} 8.2)$ ], incubated for $5 \mathrm{~min}$ at $37^{\circ} \mathrm{C}$, added $10 \mu \mathrm{l}$ of $9 \mathrm{mM}$ pyrogallol and incubated again for $5 \mathrm{~min}$ at $37^{\circ} \mathrm{C}$. After stopping the reaction with $2 \mathrm{M}$ formic buffer, absorbance was measured at $540 \mathrm{~nm}$. The SOD activity was expressed in $\mathrm{mM} / \mathrm{min} / \mathrm{mg}$ of tissue.

\section{Histopathology}

Regions of individual stomach samples, the fundus between the cardiac and pylorus were crossly trimmed based on the lumen, fixed in $10 \%$ neutral buffered formalin for $24 \mathrm{~h}$, and paraffin-embedded sections (3$4 \mu \mathrm{m})$ were prepared. Selected sections were examined under a light microscope after staining with hematoxylin and eosin. The histological profiles of changes in total thicknesses of fundic mucosa and individual cross trimmed fundus tissues were observed under a microscope at a resolution of $400 \times$. Furthermore, fundus lesion invasive percentage was also calculated according to the eq. (1) and semiquantitative scoring was assigned as follows; $0=$ normal intact mucosa, $1=$ slight surface erosive damages, $2=$ moderate mucosa damages and $3=$ severe total mucosa damages, based on general and histomorphometric analysis [35]. The histopathologist was blinded to the group distribution during analyses.

Invasive percentage of lesions (\%)

$$
\begin{aligned}
& =\left(\frac{\text { Length of lesions on the crossly trimmed fundic walls }}{\text { Total thickness of crossly trimmed fundic walls }}\right) \\
& \times 100
\end{aligned}
$$

\section{Statistical analyses}

The experimental data were expressed as mean \pm standard deviation (S.D.) of 8 rats. The variance homogeneity was estimated by the Levene's test [36]. In case of insignificant deviation, the significance between different pairs was analyzed by one-way ANOVA using LSD. In the case of significant deviation, a non-parametric comparison test (Kruskal-Wallis $\mathrm{H}$ test) was used to compare the groups. If a significant difference was observed by the Kruskal-Wallis $\mathrm{H}$ test, the significance between specific pairs was estimated by the Mann-Whitney U test. Statistical analyses were performed using SPSS ver. 14 (IBM-SPSS Inc., Chicago, IL, USA) and the results were considered statistically significant at $p<0.05$ and $p<0.01$. Furthermore, to understand the efficacy of the tested substances, the percent changes between
IND, FBe and OM treated rats were calculated by Eqs. (2) and (3), respectively [37].

$$
\begin{aligned}
& \text { Changes as compared with the intact control }(\%) \\
& =\left\{\frac{(\text { Data of IND control rats-Data of intact control rats })}{\text { Data of intact control rats }}\right\} \\
& \times 100
\end{aligned}
$$

$$
\begin{aligned}
& \text { Changes as compared with the IND control (\%) } \\
& =\left\{\frac{(\text { Data of test substance treated rats-Data of IND control rats })}{\text { Data of IND control rats }}\right\} \\
& \times 100
\end{aligned}
$$

\section{Results}

\section{Compositions of the fermented barley extract (FBe)}

Nutritional facts including calories, carbohydrates, proteins, lipids, and dietary fiber were $385.3 \mathrm{kcal} 100 \mathrm{~g}^{-1}$, 93.0, 3.1, 0.1 , and $20.20 \%$, respectively. Total polyphenols and total flavonoids contents were $3.66 \mathrm{mg} \mathrm{g}^{-1}$ and 0.31 $\mathrm{mg} \mathrm{g}^{-1}$, respectively (Table 1 ).

\section{Changes in the gastric mucosal lesions}

Slightly insignificant restricted ulcerative lesions were observed in intact control rats while focal hemorrhagic ulcerative lesions in IND treated rats were grossly dispersed in the gastric mucosa. Marked inhibitions of the gross gastric damages were noticed in $\mathrm{OM}\left(10 \mathrm{mg} \mathrm{kg}^{-1}\right)$ and $\mathrm{FBe}(100,200$, and $300 \mathrm{mg}$ $\mathrm{kg}^{-1}$ ) treated rats. Accordingly, a significant increase in gastric mucosal gross lesion areas was noticed in IND control groups compared with intact control groups, however, mucosal lesions significantly decreased in a dose-dependent manner when treated with FBe $\left(100,200\right.$, and $\left.300 \mathrm{mg} \mathrm{kg}^{-1}\right)$ or $\mathrm{OM}(10 \mathrm{mg}$ $\left.\mathrm{kg}^{-1}\right)$. An inhibitory effect on the increase in IND-induced gastric mucosal gross lesion areas was noticed in groups treated with $\mathrm{FBe}\left(200 \mathrm{mg} \mathrm{kg}^{-1}\right)$ or $\mathrm{OM}\left(10 \mathrm{mg} \mathrm{kg}^{-1}\right.$; Figs. 2 and 3).

Table 1 Composition of fermented barley extract (FBE)

\begin{tabular}{lll}
\hline Nutrition fact & Unit & Amount \\
\hline Calorie & $\mathrm{kcal} / 100 \mathrm{~g}$ & 385.3 \\
Carbohydrates & $\%$ & 93.0 \\
Protein & $\%$ & 3.1 \\
Lipids & $\%$ & 0.1 \\
Total polyphenols & $\mathrm{mg} / \mathrm{g}$ & $3.66 \pm 0.12$ \\
Total flavonoids & $\mathrm{mg} / \mathrm{g}$ & $0.31 \pm 0.02$ \\
Dietary fiber & $\%$ & 20.20 \\
\hline
\end{tabular}


A

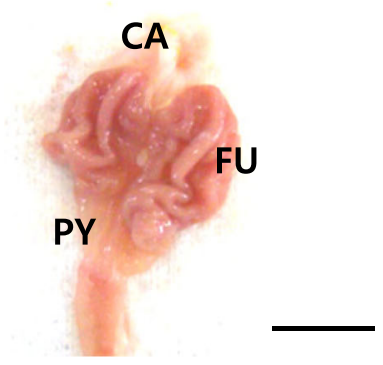

C

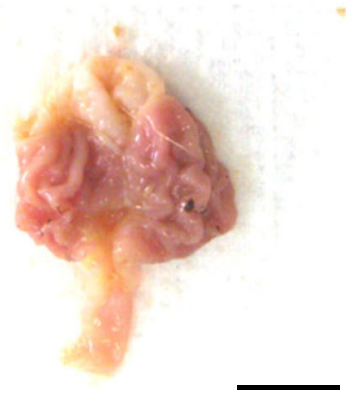

$\mathbf{E}$

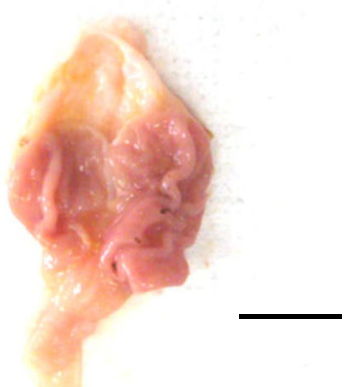

$\mathbf{B}$

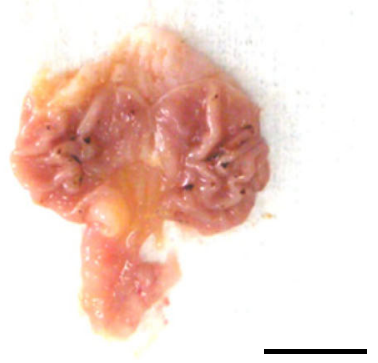

D

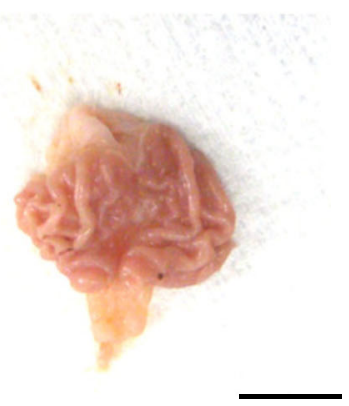

F

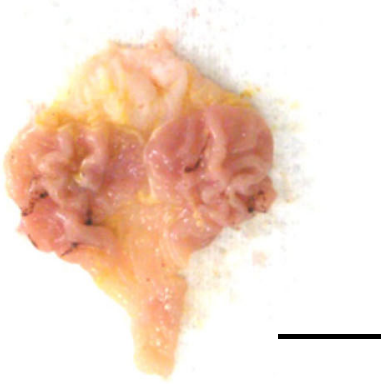

Fig. 2 Representative gross stomach images taken from intact or IND-treated mice. a: Intact control (DW $5 \mathrm{ml} \mathrm{kg}^{-1}$, twice administered rats with 30 min-intervals). b: IND control (DW $5 \mathrm{ml} \mathrm{kg}^{-1}$ and IND $25 \mathrm{mg} \mathrm{kg}^{-1}$ administered gastric mucosal damage induced vehicle control rats). c: OM (OM $10 \mathrm{mg} \mathrm{kg}^{-1}$ and IND $25 \mathrm{mg} \mathrm{kg}^{-1}$ administered reference drug treated rats). d: FBe 300 (FBe $300 \mathrm{mg} \mathrm{kg}^{-1} \mathrm{and}_{\text {IND } 25 \mathrm{mg} \mathrm{kg}}{ }^{-1}$ administered the highest dosage experimental rats). e: FBe 200 (FBe $200 \mathrm{mg} \mathrm{kg}^{-1}$ and IND $25 \mathrm{mg} \mathrm{kg}^{-1}$ administered the middle dosage experimental rats). f: FBe 100 (FBe $100 \mathrm{mg} \mathrm{kg}^{-1}$ and IND $25 \mathrm{mg} \mathrm{kg}^{-1}$ administered the lowest dosage experimental rats). FBe: triple fermented barley extract as test material; DW: Distilled water; IND: indomethacin; OM: omeprazole; CA: cardiac regions of stomach; FU: fundus regions of stomach; PY: pylorus regions of stomach. All test substances were single orally administered, at 30 min before IND $25 \mathrm{mg} \mathrm{kg}^{-1}$ single oral treatment, and all animals were sacrificed at $6 \mathrm{~h}$ after IND treatment. Scale bars $=11 \mathrm{~mm}$

\section{Effects on the gastric MPO content}

IND control groups showed a noteworthy increase in gastric MPO content compared to the intact control groups. A significant and dose-dependent decrease in MPO content was observed in rats treated with FBe $\left(100,200\right.$, and $\left.300 \mathrm{mg} \mathrm{kg}^{-1}\right)$. Furthermore, increase in IND-induced gastric MPO content was suppressed after a single oral application of OM $\left(10 \mathrm{mg} \mathrm{kg}^{-1}\right)$ which was similar to the inhibition observed by treatment with FBe (200 $\mathrm{mg} \mathrm{kg}^{-1}$; Fig. 4).

\section{Effects on the lipid peroxidation}

IND control rats showed increases in gastric lipid peroxidation compared to the intact vehicle control rats. Whereas, significant and dose-dependent decreases in lipid peroxidation were observed in FBe $(100,200$, and $300 \mathrm{mg} \mathrm{kg}^{-1}$ ) administered rats. Furthermore, IND-induced gastric lipid peroxidation was significantly suppressed after a single oral application of OM (10 mg $\mathrm{kg}^{-1}$ ) which was similar to the inhibition observed by treatment with FBe (200 $\mathrm{mg} \mathrm{kg}^{-1}$; Table 2). 


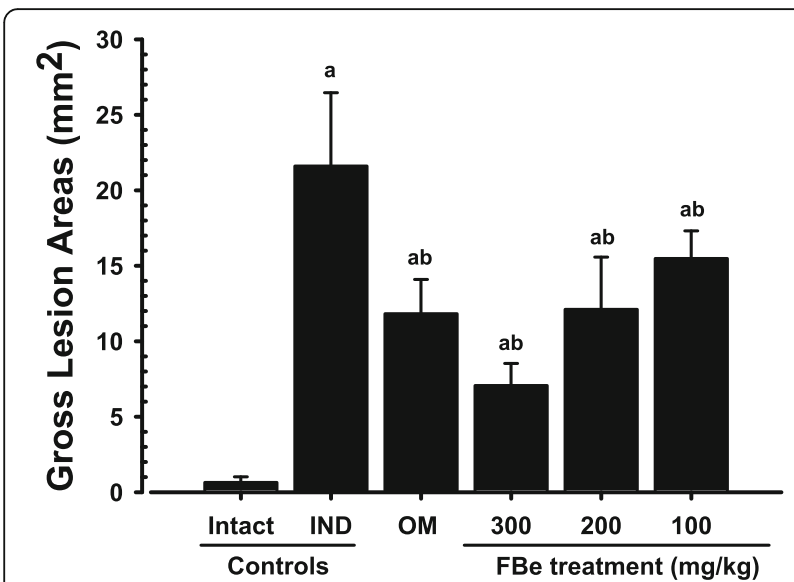

Fig. 3 Gross lesion areas on the gastric mucosa, taken from intact or IND-treated rats. Values are expressed as mean \pm S.D. of eight rats, $\mathrm{mm}^{2}$. FBe: triple fermented barley extract as test material; IND: indomethacin; OM: omeprazole. All test substances were single orally administered, at 30 min before IND $25 \mathrm{mg} \mathrm{kg}^{-1}$ single oral treatment, and all animals were sacrificed at $6 \mathrm{~h}$ after IND treatment. ${ }^{a} p<0.01$ as compared with intact control by MW test. ${ }^{b} p<0.01$ as compared with IND control by MW test

\section{Changes in the GSH contents}

Statistically significant decreases in endogenous antioxidants and gastric GSH levels were noticed in IND control rats compared to the intact control rats, but these decreases in GSH levels induced by treatment with IND were significantly suppressed after a single oral application of FBe $\left(100,200\right.$, and $\left.300 \mathrm{mg} \mathrm{kg}^{-1}\right)$ or OM $\left(10 \mathrm{mg} \mathrm{kg}^{-1}\right)$. FBe $\left(200 \mathrm{mg} \mathrm{kg}^{-1}\right)$ revealed inhibitory

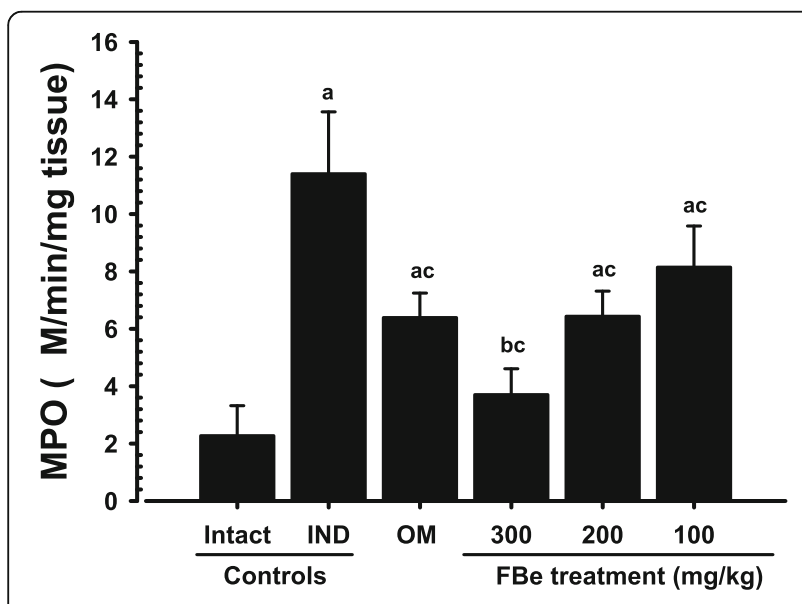

Fig. 4 Gastric MPO contents in the intact or IND-treated rats. Values are expressed as mean \pm S.D. of eight rats, $\mu \mathrm{M} / \mathrm{min} / \mathrm{mg}$ tissue. FBe: triple fermented barley extract as test material; IND: indomethacin; OM: omeprazole; MPO: myeloperoxidase. All test substances were single orally administered, at 30 min before IND $25 \mathrm{mg} \mathrm{kg}^{-1}$ single oral treatment, and all animals were sacrificed at $6 \mathrm{~h}$ after IND treatment. ${ }^{a} p<0.01$ and ${ }^{b} p<0.05$ as compared with intact control by MW test. ${ }^{c} p<0.01$ as compared with IND control by MW test effect on the decrease in IND-induced gastric GSH levels which was similar to those observed by treatment with OM (10 $\mathrm{mg} \mathrm{kg}^{-1}$; Table 2).

\section{Changes on the CAT activities}

IND control rats showed significant $(p<0.01)$ increases in gastric CAT activity as compared to the intact control rats, but these elevations of CAT activities induced by treatment of IND were significantly suppressed after a single oral application of FBe $\left(100,200\right.$, and $\left.300 \mathrm{mg} \mathrm{kg}^{-1}\right)$ or $\mathrm{OM}\left(10 \mathrm{mg} \mathrm{kg}^{-1}\right)$. FBe at a dosage of $200 \mathrm{mg} \mathrm{kg}^{-1}$. revealed similar inhibitory effect on the increase in IND-induced gastric CAT activities compared to those observed by treatment with OM (10 $\mathrm{mg} \mathrm{kg}^{-1}$; Table 2).

\section{Effects on the SOD activities}

IND control groups showed significant decreases in gastric SOD activities compared to the intact vehicle control groups. However, FBe $(100,200$, and $300 \mathrm{mg} \mathrm{kg}$ 1) treated rats showed significant $(p<0.01)$ and dose-dependent increases in SOD activities. Furthermore, the decrease in IND-induced gastric SOD activity was significantly suppressed after a single oral application of FBe (200 $\left.\mathrm{mg} \mathrm{kg}^{-1}\right)$ or OM (10 $\mathrm{mg} \mathrm{kg}^{-1}$; Table 2).

\section{Changes in the gastric mucosal histopathology}

Severe desquamation of focal epithelium, focal extensive superficial epithelial damage, congestion/ hemorrhages, and necrosis of ulcerative lesions and gastric glands were observed following treatment with IND in rats. However, these microscopic ulcerative lesions were significantly suppressed by treatment with test materials. During histomorphometric and semiquantitative analyses, a significant increase in semiquantitative histological scores and percentage of invaded lesions, and a decrease in peri-ulcerative mucosa thickness were noticed in IND control rats compared to the intact vehicle control rats. But, these changes were significantly regulated by treatment with FBe $\left(100,200\right.$, and $\left.300 \mathrm{mg} \mathrm{kg}^{-1}\right)$. Furthermore, a significant decrease in semiquantitative histological scores and percentage of invaded lesions, and an increase in peri-ulcerative mucosa thickness were noticed in $\mathrm{OM}\left(10 \mathrm{mg} \mathrm{kg}^{-1}\right)$ administered rats compared to the IND control rats. FBe $\left(200 \mathrm{mg} \mathrm{kg}^{-1}\right)$ revealed inhibitory effect on the IND-induced histopathological gastric mucosal damages which was similar to those noticed in rats treated with $\mathrm{OM}\left(10 \mathrm{mg} \mathrm{kg}^{-1}\right.$; Table 3, Fig. 5).

\section{Discussion}

Mucosal damages can be easily generated by exogenous and endogenous ROS and free radicals [38]. Changes in the gastric mucosal antioxidant defense system have been linked with the pathogenesis and progression of 
Table 2 Gastric lipid peroxidation, glutathione contents, CAT, and SOD activities in the intact or IND-treated rats

\begin{tabular}{|c|c|c|c|c|}
\hline \multirow[t]{2}{*}{ Items (Unit) groups } & \multirow{2}{*}{$\begin{array}{l}\text { Lipid peroxidation } \\
\text { (nM of MDA/g tissue) }\end{array}$} & \multirow{2}{*}{$\begin{array}{l}\text { Glutathione contents } \\
\text { (nM/mg tissue) }\end{array}$} & \multicolumn{2}{|l|}{ Enzyme activity } \\
\hline & & & CAT (mM/min /g tissue) & $\mathrm{SOD}(\mathrm{mM} / \mathrm{min} / \mathrm{mg}$ tissue $)$ \\
\hline \multicolumn{5}{|l|}{ Control } \\
\hline Intact & $2.73 \pm 1.15$ & $5.21 \pm 1.34$ & $87.75 \pm 17.29$ & $151.50 \pm 16.58$ \\
\hline IND & $20.02 \pm 3.60^{\mathrm{a}}$ & $1.49 \pm 0.22^{d}$ & $174.25 \pm 26.86^{\mathrm{a}}$ & $75.75 \pm 12.63^{\mathrm{a}}$ \\
\hline \multicolumn{5}{|l|}{ Reference } \\
\hline OM $10 \mathrm{mg} \mathrm{kg}^{-1}$ & $12.91 \pm 2.96^{\mathrm{ac}}$ & $2.37 \pm 0.42^{\mathrm{d}, \mathrm{e}}$ & $126.63 \pm 14.92^{\mathrm{a}, \mathrm{c}}$ & $113.88 \pm 10.74^{\mathrm{a}, \mathrm{c}}$ \\
\hline \multicolumn{5}{|l|}{ FBe treated as } \\
\hline $100 \mathrm{mg} \mathrm{kg}^{-1}$ & $15.56 \pm 1.95^{\mathrm{a}, \mathrm{c}}$ & $2.05 \pm 0.34^{\mathrm{d}, \mathrm{e}}$ & $142.13 \pm 13.42^{\mathrm{a}, \mathrm{c}}$ & $100.38 \pm 18.91^{\mathrm{a}, \mathrm{c}}$ \\
\hline $200 \mathrm{mg} \mathrm{kg}^{-1}$ & $13.01 \pm 2.16^{\mathrm{a}, \mathrm{c}}$ & $2.56 \pm 0.68^{\mathrm{d}, e}$ & $124.75 \pm 19.31^{\mathrm{a}, \mathrm{c}}$ & $115.00 \pm 11.99^{\mathrm{a}, \mathrm{c}}$ \\
\hline $300 \mathrm{mg} \mathrm{kg}^{-1}$ & $6.11 \pm 1.79^{\mathrm{a}, \mathrm{c}}$ & $3.37 \pm 0.54^{d, e}$ & $109.63 \pm 16.40^{\mathrm{b}, \mathrm{c}}$ & $131.00 \pm 15.15^{\mathrm{a}, \mathrm{c}}$ \\
\hline
\end{tabular}

Values are expressed as mean \pm S.D. of eight rats

FBe triple fermented barley extract as test material, IND indomethacin, OM omeprazole, MDA malondialdehyde, CAT catalase, SOD superoxide dismutase ${ }^{\mathrm{a}} p<0.01$

${ }^{\mathrm{b}} p<0.05$ as compared with intact control by LSD test

$c_{p}<0.01$ as compared with IND control by LSD test

${ }^{d} p<0.01$ as compared with intact control by MW test

$e^{e}<0.01$ as compared with IND control by MW test

NSAIDs associated gastric ulcers [11]. Indomethacin, an NSAID, is widely approved in medical practice [7]; however, an ulcerative gastrointestinal effect may arise from the inhibition of prostaglandin synthesis [8] and harmful ROS generations [38]. The antioxidants are advocated to offer effective protection against induction and progression of gastric ulcers $[39,40]$, and the fermentation processes are linked with increased bioavailability of various phenolic compounds and antioxidants [15, 41, 16-18]. The reported medicinal attributes and antioxidant properties of the natural substances prompted our assessment of the possible protective effects of FBe against IND-induced gastric lesions in Sprague-Dawley rat model.

The decrease in the gross hemorrhagic lesion area was considered as an indicator of the protective effects of the test substances on the gastric mucosa corroborating previous efficacy studies [28, 42]. Lesser gross lesions are equal to more favorable protective effects [10]. FBe (200 $\mathrm{mg} \mathrm{kg}^{-1}$ ) inhibited the gastric gross lesion areas and showed similar gastroprotective effects as those observed with $\mathrm{OM}\left(10 \mathrm{mg} \mathrm{kg}^{-1}\right)$ in IND-induced gastric mucosal damaged rats. This suggests that FBe dosage can be

Table 3 Histomorphometrical analysis on the fundus, taken from intact or IND-treated rats

\begin{tabular}{|c|c|c|c|}
\hline \multirow{2}{*}{$\begin{array}{l}\text { Items (Unit) } \\
\text { groups }\end{array}$} & \multicolumn{3}{|l|}{ Histomorphometry (at sacrifice) } \\
\hline & Invasive percentages of lesions* (\%) & Mean peri-ulcerative mucosa thickness $(\mu \mathrm{m})$ & Semiquantitative scores (Max $=3$ ) \\
\hline \multicolumn{4}{|l|}{ Control } \\
\hline Intact & $4.27 \pm 2.87$ & $902.66 \pm 131.22$ & $0.38 \pm 0.52$ \\
\hline IND & $68.53 \pm 12.68^{\mathrm{e}}$ & $281.50 \pm 87.64^{\mathrm{a}}$ & $2.75 \pm 0.46^{\mathrm{a}}$ \\
\hline \multicolumn{4}{|l|}{ Reference } \\
\hline OM $10 \mathrm{mg} \mathrm{kg}^{-1}$ & $26.65 \pm 15.66^{\mathrm{e}, \mathrm{f}}$ & $538.88 \pm 87.26^{\mathrm{a}, \mathrm{b}}$ & $1.38 \pm 0.52^{\mathrm{a}, \mathrm{b}}$ \\
\hline \multicolumn{4}{|l|}{ FBe treated as } \\
\hline $100 \mathrm{mg} \mathrm{kg}^{-1}$ & $32.59 \pm 14.44^{\mathrm{e}, \mathrm{f}}$ & $410.09 \pm 58.15^{a, c}$ & $2.00 \pm 0.53^{\mathrm{a}, \mathrm{b}}$ \\
\hline $200 \mathrm{mg} \mathrm{kg}^{-1}$ & $25.63 \pm 10.67^{e, f}$ & $521.04 \pm 90.25^{a, b}$ & $1.50 \pm 0.53^{\mathrm{a}, \mathrm{b}}$ \\
\hline $300 \mathrm{mg} \mathrm{kg}^{-1}$ & $13.00 \pm 5.46^{\mathrm{e}, \mathrm{f}}$ & $635.59 \pm 129.75^{\mathrm{a}, \mathrm{b}}$ & $1.13 \pm 0.64^{\mathrm{a}, \mathrm{b}}$ \\
\hline
\end{tabular}

Values are expressed as mean \pm S.D. of eight rat samples

$F B e$ triple fermented barley extract as test material, IND indomethacin, OM omeprazole

*Invasive percentage of lesions $(\%)=\left(\frac{\text { Length of lesions on the crossly trimmed fundic walls }}{\text { Total thichess of crossly trimmed fundic walls }}\right) \times 100$

Semiquantitative scoring was divided into four groups; 0: normal intact mucosa, 1: slight surface erosive damages, 2: moderate mucosa damages, and 3: severe total mucosa damages

${ }^{a} p<0.01$ as compared with intact control by LSD test

${ }^{\mathrm{b}} p<0.01$ and ${ }^{\mathrm{c}} p<0.05$ as compared with IND control by LSD test

${ }^{\mathrm{d}} p<0.01$ as compared with intact control by MW test

${ }^{\mathrm{e}} p<0.01$ as compared with IND control by MW test 


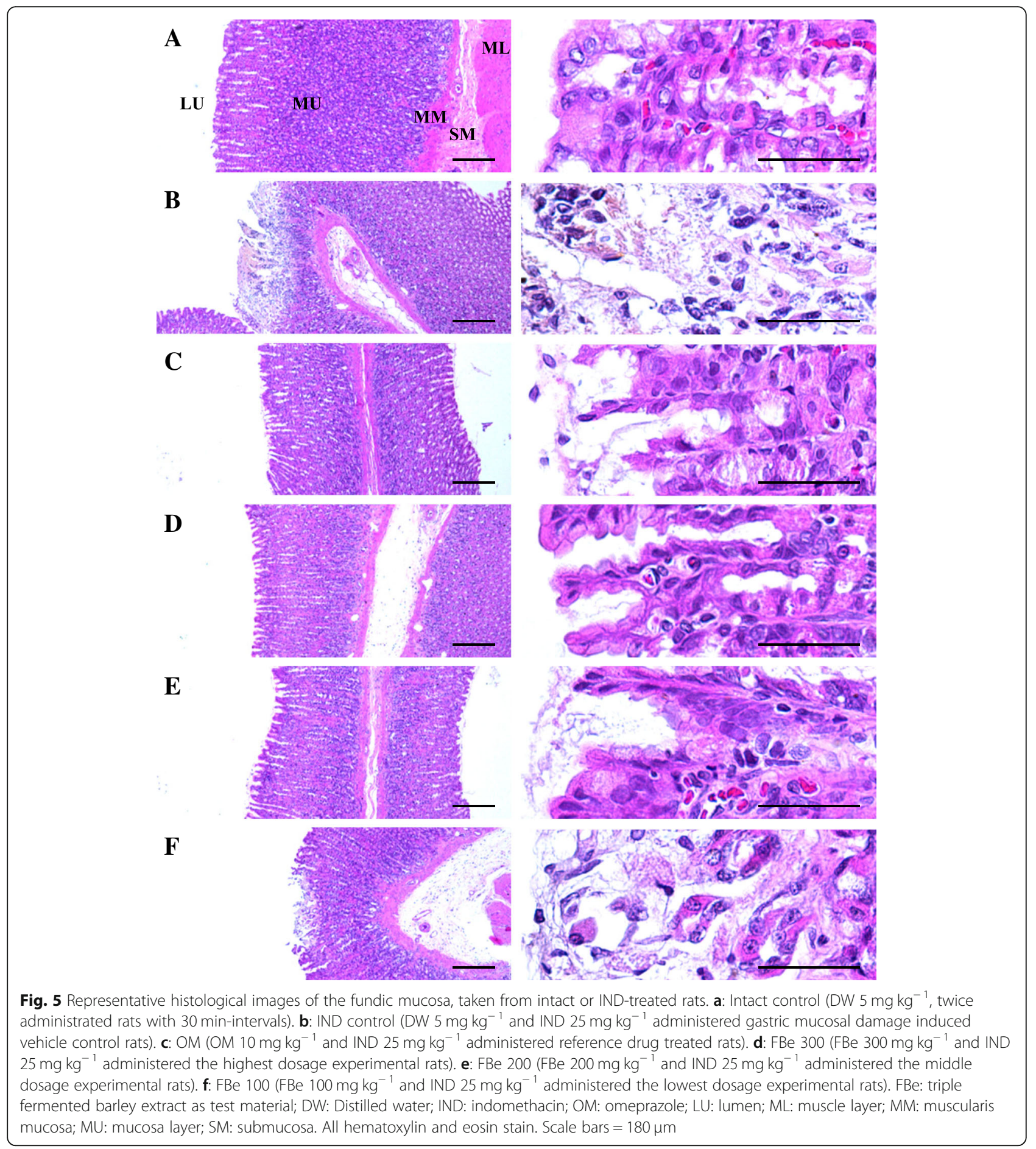

effectively regulated for patients undergoing various gastric disorders, starting with a dose of $100 \mathrm{mg} \mathrm{kg}^{-1}$.

IND markedly enhanced the MPO activity in stomach tissue whereas all three doses of FBe significantly lowered the MPO activity. FBe $\left(200 \mathrm{mg} \mathrm{kg}^{-1}\right)$ displayed inhibitory effect on the increase of IND-induced MPO activities similar to those observed on treatments with OM. An increase in MPO activity has been reported in NSAID-damaged stomach tissue [40], which shows increased neutrophil secretion in stomach lesions [43]. Excessive secretions of free radicals such as $\mathrm{OH}, \mathrm{H}_{2} \mathrm{O}_{2}$, and $\mathrm{O}_{2}$ due to the neutrophil secretion cause tissue damages [43]. Therefore, the dose-dependent decreases in MPO activity after a single oral administration of $\mathrm{FBe}$ demonstrate that FBe has favorable anti-inflammatory effects, and can 
suppress the harmful effects of infiltrated neutrophils in gastric mucosa induced by IND treatment.

All tested doses of FBe markedly lowered the lipid peroxidation (MDA content) compared to the IND control. FBe $\left(200 \mathrm{mg} \mathrm{kg}^{-1}\right)$ also decreased the MDA level in a similar manner as OM. The increase in MDA level is associated with increased tissue damage and it is an important cause of gastric damages associated with NSAIDs [44, 45].

GSH and other antioxidant mechanisms regulate the ROS at a specific required cellular concentration which prevents tissue damage [46]. The GSH levels in the stomach tissue of FBe $\left(200 \mathrm{mg} \mathrm{kg}^{-1}\right)$-administered rats were statistically higher compared to those observed in the IND control rats. Especially, higher GSH levels were observed in the stomach tissues with less damage. This increase in GSH levels is associated with gastroprotective effects of $\mathrm{FBe}$ and illustrates that the FBe dosage can be easily regulated for patients suffering from different levels of gastric damages.

Statistically different CAT activity was observed in stomach tissue of the healthy rats and the IND control rats. CAT activity in the $\mathrm{FBe}\left(200 \mathrm{mg} \mathrm{kg}^{-1}\right)$-administered rats decreased significantly in a dose-dependent manner. Previous studies have shown an increasing trend in CAT activity in the IND-induced stomach damages $[47,48]$. The increased CAT activity in IND-administered groups shows an increase in $\mathrm{H}_{2} \mathrm{O}_{2}$ while the decreased CAT activity in FBe-administered groups indicates a decreased oxidative stress.

The outcomes of this study support earlier studies stating that NSAIDs lower SOD activity in rat stomach tissues [47, 48]. SOD activity was inhibited in IND-administered rats; however, FBe and OM showed higher SOD activity. FBe $\left(200 \mathrm{mg} \mathrm{kg}^{-1}\right)$ showed an inhibitory effect against IND-induced SOD activity inhibition similar to those observed on treatment with OM. SOD and other antioxidants are important in reducing IND-induced gastric damage as it partially prevents oxidative damages [49]. The relationship between prostaglandin synthesis and SOD activity has been studied in details and it is considered as a possible mechanism of IND-induced ulcers [46, 49].

Gastric mucosal histopathological analysis revealed enhanced focal extensive desquamation of focal epithelium superficial epithelial damage, focal hemorrhages/congestions, neutrophil necrosis and infiltrations of gastric glands, and ulcerative lesions. The findings of this study were similar to the previously reported studies of Bhattacharya et al. [6], and Graziani et al. [50]. Histopathological analysis has been used as a valuable criterion to estimate the gastroprotective effects of new medicinal products, including herbal extracts $[10,51,52]$. In the present study, OM and FBe significantly inhibited the
IND associated microscopic ulcerative lesions in a dose-dependent manner. FBe $\left(200 \mathrm{mg} \mathrm{kg}^{-1}\right)$ exhibited a histopathological effect similar to that observed in treatment with OM. The changes were re-confirmed by histomorphometric analysis. Peri-ulcerative mucosal thickness was significantly decreased while the percentage of invaded lesions and the semiquantitative histological scores were prominently increased in IND treatment group. However, the changes were favorably normalized in a dose-dependent manner with FBe and after a single oral application of OM. The changes observed in OM treatment were similar to those observed in treatment with FBe $\left(200 \mathrm{mg} \mathrm{kg}^{-1}\right)$.

The acute toxicity profile of the test material (FBe), analyzed in a previous study by our group [21], showed non-toxic behavior of FBe to mice, and therefore, it was considered likely to be safe for medical use. A single oral application of FBe showed an $\mathrm{LD}_{50}$ of $>2000 \mathrm{mg} \mathrm{kg}^{-1}$, which is the KFDA (Korean Food and Drug Administration) recommended dose for both male and female rodents. FBe in this study showed a significant and dose-dependent decrease in IND-induced gastric damage, the hemorrhagic gross lesion, gastric MPO content, and histopathological gastric ulcerative lesion. Additionally, FBe dose-dependently strengthened the antioxidant defense systems, lowered lipid peroxidation level, and CAT activity but enhanced the SOD activity and GSH content. Similar results were obtained in our previous study on the gastroprotective effect of $\mathrm{FBe}$ on $\mathrm{HCl} / \mathrm{Et}-\mathrm{OH}$-induced gastric mucosal damage in mice [53]. FBe $\left(200 \mathrm{mg} \mathrm{kg}^{-1}\right)$ showed promising gastroprotective effects in the present study on indomethacin-induced gastric ulcer in rats and in the previous study on $\mathrm{HCl} /$ Et-OH-induced gastric ulcer in mice [53]. The inhibitory effects were similar to the commercially available anti-ulcer drugs, such as ranitidine $\left(100 \mathrm{mg} \mathrm{kg}^{-1}\right)$ and omeprazole $\left(10 \mathrm{mg} \mathrm{kg}^{-1}\right)$. In our previously study, FBe (200 and $300 \mathrm{mg} \mathrm{kg}^{-1}$ ) also indicated satisfactory laxative effects, mediated by the increase in gastrointestinal motility in normal rats [20]. Hence, FBe, as a potent food supplement, can be suitable for patients suffering from gastric mucosal disorders.

The findings of this study are considered as direct evidence that oral administration of FBe had promising gastroprotective effects by strengthening the anti-inflammatory effects and the innate antioxidant defense system. It has been reported that the polyphenols and total flavonoids have potent antioxidant and anti-inflammatory effects. Thus, the total polyphenols and flavonoids contents of $\mathrm{FBe}$ may be responsible for the anti-inflammatory, antioxidant, and gastroprotective effects of FBe. Further research is needed to elucidate the specific polyphenols and flavonoids responsible for its antioxidant and anti-inflammatory effects. 


\section{Conclusions}

By evaluating the important parameters for protective effects on the Sprague-Dawley rats with IND-induced gastric mucosal damage, during this study oral supply of FBe $\left(100,200\right.$, and $\left.300 \mathrm{mg} \mathrm{kg}^{-1}\right)$ revealed promising gastroprotective effects by strengthening the anti-inflammatory effects and the antioxidant defense system. Moreover, the experimental results also showed that FBe $\left(200 \mathrm{mg} \mathrm{kg}^{-1}\right)$ had similar inhibitory effects against IND-induced gastric damage in rats to those observed in treatment with $\mathrm{OM}\left(10 \mathrm{mg} \mathrm{kg}^{-1}\right)$, indicating that $\mathrm{FBe}$ dosage can be easily regulated for patients suffering from different levels of gastric damages, starting at a dosage of $100 \mathrm{mg} \mathrm{kg}^{-1}$ as observed in IND-induced gastric damages in rats.

\section{Abbreviations}

ATCC: American type culture collection; CAT: catalase; EDTA: ethylene diamine tetraacetic acid; FBe: triple fermented barley extract; GSH: glutathione; H\&E: hematoxylin and eosin stain; HETAB: hexadecyltrimethylammonium bromide; IND: indomethacin; KACC: Korean Agricultural Culture Collection; MDA: malondialdehyde; MPO: myeloperoxidase; NBF: neutral buffered formalin; NSAIDs: non-steroidal anti-inflammatory drugs; OM: omeprazole; PPI: proton pump inhibitor; ROS: reactive oxygen species; SOD: superoxide dismutase

\section{Acknowledgments}

Not applicable.

\section{Funding}

No funding was received for this study.

\section{Availability of data and materials}

Data supporting the conclusions of this study are contained in the article and on reasonable request, the primary data can be provided from the corresponding author.

\section{Authors' contributions}

JML, JSC designed the experiment; JML, GWJ, KMIB prepared experimental samples and performed analytic experiments; CHS, SJP, DCP performed animal experiments; HRC, SKK, JSC prepared the manuscript. All authors have gone through and approved the manuscript. SK Ku and J-S Choi contributed equally to this work.

\section{Ethics approval and consent to participate}

All procedures performed in this study involving animals were in accordance with the ethical standards and the international regulations of the usage and welfare of laboratory animals and were approved by the Institutional Animal Care and Use Committee of Daegu Haany University, Gyeongsan, Rep. of Korea [Approval No: DHU2014-087].

\section{Consent for publication}

Not applicable.

\section{Competing interests}

The authors declare that they have no competing interests.

\section{Publisher's Note}

Springer Nature remains neutral with regard to jurisdictional claims in published maps and institutional affiliations.

\section{Author details}

'Glucan Corp., \#305 Marine Bio-Industry Development Center, Hoenggye-ri 27, llgwang-myeon, Gijan-gun, Busan 46048, Republic of Korea. ${ }^{2}$ Department of Anatomy and Histology, College of Korean Medicine, Daegu Haany University, 290 Yugok-dong, Gyeongsan-si, Gyeongsanbuk-do 38610,
Republic of Korea. ${ }^{3}$ MRC-GHF, College of Korean Medicine, Daegu Haany University, 290 Yugok-dong, Gyeongsan-si, Gyeongsanbuk-do 38610, Republic of Korea. ${ }^{4}$ Research Center for Extremophiles and Microbiology, College of Medical and Life Sciences, Silla University, 140, Baegyang-daero 700 beon-gil, Sasang-gu, Busan 46958, Republic of Korea. ${ }^{5}$ Research Center for Life Science Technologies in Medicine and Environment, 31,

Gwahaksandan 1-ro, 60 beon-gil, Gangseo-gu, Busan 46742, Republic of Korea. ${ }^{6}$ Division of Bioindustry, College of Medical and Life Sciences, Silla University, 140, Baegyang-daero, 700 beon-gil, Sasang-gu, Busan 46958, Republic of Korea.

Received: 25 July 2018 Accepted: 12 February 2019

Published online: 20 February 2019

\section{References}

1. Feldman M, Friedman LS, Brandt LJ. Sleisenger and Fordtran's gastrointestinal and liver disease-2 volume set. In: Pathophysiology, Diagnosis, Management. 10th ed. Philadelphia, PA: Elsevier Saunders Co.; 2016.

2. Sharkey KA, MacNaughton WK. Pharmacotherapy of gastric acidity, peptic ulcers, and gastroesophageal reflux disease. In: Brunton LL, Hilal-Dandan R, Knollman BC, editors. Goodman and Gilman's: The pharmacological basis of therapeutics. 13th ed. New York: McGraw-Hill; 2018.

3. Coruzzi G, Menozzi A, Dobrilla G. Novel non-steroidal anti-inflammatory drugs: what we have learned from animal studies. Curr Drug Targets Inf amm Allergy. 2004;3:43-61 https://doi.org/10.2174/1568010043483971.

4. Wolfe MM, Lichtenstein DR, Singh G. Gastrointestinal toxicity of nonsteroidal antiinflammatory drugs. N Engl J Med. 1999;340:1888-99 https://doi.org/10. 1056/NEJM199906173402407.

5. Dhikav V, Singh S, Pande S, Chawla A, Anand KS. Nonsteroidal drug-induced gastrointestinal toxicity: mechanisms and management. J Indian Clin Med. 2003:4:315-22.

6. Bhattacharya S, Banerjee D, Bauri AK, Chattopadhyay S, Bandyopadhyay SK. Healing property of the Piper betel phenol, allylpyrocatechol against indomethacin-induced stomach ulceration and mechanism of action. World J Gastroenterol. 2007;13:3705-13 https://doi.org/10.3748/wjg.v13.i27.3705.

7. Simmons DL, Botting RM, Hla T. Cyclooxygenase isozymes: the biology of prostaglandin synthesis and inhibition. Pharmacol Rev. 2004;56:387-437 https://doi.org/10.1124/pr.56.3.3.

8. Kataoka H, Horie Y, Koyama R, Nakatsugi S, Furukawa M. Interaction between NSAIDs and steroid in rat stomach: safety of nimesulide as a preferential COX-2 inhibitor in the stomach. Dig Dis Sci. 2000;45:1366-75 https://doi.org/10.1023/A:1005560104847.

9. Silve MIG, de Sousa FCF. Gastric ulcer etiology. In: Chai J, editor. Peptic ulcer disease. Shanghai, China: InTake; 2011. p. 2-28.

10. Oyagi A, Ogawa K, Kakino M, Hara H. Protective effects of a gastrointestinal agent containing Korean red ginseng on gastric ulcer models in mice. BMC Complement Altern Med. 2010;10:45 https://doi.org/10.1 186/1472-6882-10-45.

11. Kwiecień S, Brzozowski T, Konturek PCH, Konturek SJ. The role of reactive oxygen species in action of nitric oxide-donors on stress-induced gastric mucosal lesions. J Physiol Pharmacol. 2002;53:761-73.

12. Jung YM, Lee SH, Lee DS, You MJ, Chung IK, Cheon WH, Kwon YS, Lee YJ, Ku SK. Fermented garlic protects diabetic, obese mice when fed a high-fat diet by antioxidant effects. Nutr Res. 2011;31:387-96 https://doi.org/10.1016/ j.nutres.2011.04.005.

13. Kim CM, Yi SJ, Cho IJ, Ku SK. Red-koji fermented red ginseng ameliorates high fat diet-induced metabolic disorders in mice. Nutrients. 2013;5:4316-32 https://doi.org/10.3390/nu5114316.

14. Jung HJ, Choi H, Lim HW, Shin D, Kim H, Kwon B, Lee JE, Park EH, Lim CJ. Enhancement of anti-inflammatory and antinociceptive actions of red ginseng extract by fermentation. J Pharm Pharmacol. 2012;64:756-62 https://doi.org/10.1111/j.2042-7158.2012.01460.x.

15. Giriwono PE, Shirakawa H, Hokazono H, Goto T, Komai M. Fermented barley extract supplementation maintained antioxidative defense suppressing lipopolysaccharide-induced inflammatory liver injury in rats. Biosci Biotechnol Biochem. 2011;75:1971-6 https://doi.org/10.1271/bbb.110374.

16. Hokazono H, Omori T, Ono K. Effects of single and combined administration of fermented barley extract and gamma-aminobutyric acid on the development of atopic dermatitis in NC/Nga mice. Biosci Biotechnol Biochem. 2010;74:135-9 https://doi.org/10.1271/bbb.90653. 
17. Hokazono H, Omori T, Yamamoto T, Akaoka I, Ono K. Effects of a fermented barley extract on subjects with slightly high serum uric acid or mild hyperuricemia. Biosci Biotechnol Biochem. 2010;74:828-34 https://doi.org/ 10.1271/bbb.90936.

18. Kim HB, Lee HS, Kim SJ, Yoo HJ, Hwang JS, Chen G, Youn HJ. Ethanol extract of fermented soybean, Chungkookjang, inhibits the apoptosis of mouse spleen, and thymus cells. J Microbiol. 2007;45:256-61.

19. Oh TY, Shin CY, Sohn YS, Kim DH, Ahn BO, Lee EB, Park CH. Therapeutic effect of DA-9601 on chronic reflux gastritis induced by sodium taurocholate in rats. World J Gastroenterol. 2005;11:7430-5 https://doi.org/ 10.3748/wjg.v11.i47.7430.

20. Lim J-M, Song C-H, Park S-J, Park D-C, Jung G-W, Cho H-R, Ku SK, Choi J-S. Laxative effects of triple-fermented barley extracts (FBe) in normal rats. Toxicol Environ Health Sci. 2018;10:107-17 https://doi.org/10.1007/s13530-018-0353-5.

21. Lim J-M, Park D-C, Cho H-R, Jung G-W, Ku SK, Choi J-S. Acute toxicity test of triple fermented barley extracts (FBe) in mice after oral administration. Toxicol. Environ. Health Sci. 2017;9:332-45 https://doi.org/10.1007/s13530-017-0339-8.

22. Choi JS, Kim JW, Cho HR, Kim KY, Lee JK, Ku SK, Sohn JH. Laxative effects of fermented rice extract (FRe) in normal rats. Toxicol Environ Health Sci. 2014; 6:155-63 https://doi.org/10.1007/s13530-014-0200-2.

23. Choi JS, Kim JW, Cho HR, Kim KY, Lee JK, Sohn JH, Ku SK. Laxative effects of fermented rice extract in rats with loperamide-induced constipation. Exp Ther Med. 2014;8:1847-54 https://doi.org/10.3892/etm.2014.2030.

24. Choi JS, Kim JW, Kim KY, Lee JK, Sohn JH, Ku SK. Synergistic effect of fermented rice extracts on the probiotic and laxative properties of yoghurt in rats with loperamide-induced constipation. Evid Based Complement Alternat Med. 2014 2014:878503 https://doi.org/10.1155/2014/878503.

25. Choi JS, Kim JW, Kim KY, Ku SK, Sohn JH. Single-dose oral toxicity of fermented rice extracts (FREs): a 14-day observation. Pak J Pharm Sci. 2014:27:129-37.

26. Ministry of Food Drug Safety (MFDS). Food Code. Korean Foods Industry Association, Seoul, Korea. 2014

27. Ministry of Food Drug Safety (MFDS). Health Functional Food Code. Korean Foods Industry Association, Seoul, Korea. 2017.

28. Suleyman H, Cadirci E, Albayrak A, Polat B, Halici Z, Koc F, Hacimuftuoglu A, Bayir Y. Comparative study on the gastroprotective potential of some antidepressants in indomethacin-induced ulcer in rats. Chem Biol Interact. 2009;180:318-24 https://doi.org/10.1016/j.cbi.2009.03.002.

29. Morais TC, Pinto NB, Carvalho KM, Rios JB, Ricardo NM, Trevisan MT, Rao VS, Santos FA. Protective effect of anacardic acids from cashew (Anacardium occidentale) on ethanol-induced gastric damage in mice. Chem Biol Interact. 2010;183:264-9 https://doi.org/10.1016/j.cbi.2009.10.008.

30. Bradley PP, Priebat DA, Christensen RD, Rothstein G. Measurement of cutaneous inflammation: estimation of neutrophil content with an enzyme marker. J Invest Dermatol. 1982;78:206-9 https://doi.org/10.1111/1523-1747. ep12506462.

31. Ohkawa H, Ohishi N, Yagi K. Assay for lipid peroxides in animal tissues by thiobarbituric acid reaction. Anal Biochem. 1979;95:351-8 https://doi.org/10. 1016/0003-2697(79)90738-3.

32. Sedlak J, Lindsay RH. Estimation of total, protein-bound, and nonprotein sulfhydryl groups in tissue with Ellman's reagent. Anal Biochem. 1968;25: 192-205 https://doi.org/10.1016/0003-2697(68)90092-4.

33. Evans RC, Diplock AT. Laboratory techniques in biochemistry and molecular biology. In: Techniques in free radical research. Burtin $\mathrm{RH}$ and Knippenberg PH (ed). Elsevier, Amsterdam. 1991. pp. 199-201.

34. Bashir KMI, Md. M, An JH, Choi J-Y, Hong Y-K, Sohn JH, Kim J-S, Choi J-S. In vivo antioxidant activity of mackerel (Scomber japonicus) muscle protein hydrolysate. Peer J. 2018;6:e6181 https://doi.org/10.7717/peerj.6181.

35. Ku SK, Seo BI, Park JH, Park GY, Seo YB, Kim JS, Lee HS, Roh SS. Effect of Lonicerae flos extracts on reflux esophagitis with antioxidant activity. World J Gastroenterol. 2009;15:4799-805 https://doi.org/10.3748/wjg.15.4799.

36. Levene A. Pathological factors influencing excision of tumours in the head and neck. Part I Clin Otolaryngol Allied Sci. 1981;6:145-51 https://doi.org/10. 1111/j.1365-2273.1981.tb01800.x.

37. Kang SJ, Lee JE, Lee EK, Jung DH, Song CH, Park SJ, Choi SH, Han CH, Ku SK, Lee YJ. Fermentation with Aquilariae lignum enhances the anti-diabetic activity of green tea in type II diabetic $d b / d b$ mouse. Nutrients. 2014;6:353671 https://doi.org/10.3390/nu6093536

38. Sen S, Chakraborty R, Sridhar C, Reddy YSR, De B. Free radicals, antioxidants, diseases and phytomedicines: current status and future prospect. Int J Pharm Sci Rev Res. 2010;3:91-100.
39. Santos FA, Rao VS. 1,8-cineol, a food flavoring agent, prevents ethanolinduced gastric injury in rats. Dig Dis Sci. 2001;46:331-7 https://doi.org/10. 1023/A:1005604932760.

40. Bilici D, Suleyman H, Banoglu ZN, Kiziltunc A, Avci B, Ciftcioglu A, Bilici S. Melatonin prevents ethanol-induced gastric mucosal damage possibly due to its antioxidant effect. Dig Dis Sci. 2002;47:856-61 https://doi.org/10.1023/ A:1014764705864

41. Iguchi T, Kawata A, Watanabe T, Mazumder TK, Tanabe S. Fermented barley extract suppresses the development of atopic dermatitis-like skin lesions in NC/Nga mice, probably by inhibiting inflammatory cytokines. Biosci Biotechnol Biochem. 2009;73:489-93 https://doi.org/10.1271/bbb.80436.

42. Mori J, Hayashi T, Iwashima M, Matsunaga T, Saito H. Effects of plastoquinones from the brown alga Sargassum micracanthum and a new chromene derivative converted from the plastoquinones on acute gastric lesions in rats. Biol Pharm Bull. 2006;29:1197-201 https://doi.org/10.1248/bpb.29.1197.

43. Bayir Y, Odabasoglu F, Cakir A, Aslan A, Suleyman H, Halici M, Kazaz C. The inhibition of gastric mucosal lesion, oxidative stress and neutrophilinfiltration in rats by the lichen constituent diffractaic acid. Phytomedicine. 2006;13:584-90 https://doi.org/10.1016/j.phymed.2005.07.002.

44. Lim J-M, Lee YJ, Cho H-R, Park D-C, Jung G-W, Ku SK, Choi J-S. Extracellular polysaccharides purified from Aureobasidium pullulans SM-2001 (Polycan) inhibit dexamethasone-induced muscle atrophy in mice. Int J Mol Med. 2017;41:1245-64 https://doi.org/10.3892/ijmm.2017.3251.

45. Ayala A, Muñoz MF, Argüelles S. Lipid peroxidation: production, metabolism, and signaling mechanisms of malondialdehyde and 4Hydroxy-2-Nonenal. Oxidative Med Cell Longev. 2014;360438:1-31 https:// doi.org/10.1155/2014/360438.

46. Ajaikumar KB, Asheef $M$, Babu BH, Padikkala J. The inhibition of gastric mucosal injury by Punica granatum L. (pomegranate) methanolic extract. J Ethnopharmacol. 2005;96:171-6 https://doi.org/10.1016/j.jep.2004.09.007.

47. Basivireddy J, Jacob M, Ramamoorthy P, Pulimood AB, Balasubramanian KA. Indomethacin-induced free radical-mediated changes in the intestinal brush border membranes. Biochem Pharmacol. 2003;65:683-95 https://doi.org/10. 1016/S0006-2952(02)01616-7.

48. Odabasoglu F, Cakir A, Suleyman H, Aslan A, Bayir Y, Halici M, Kazaz C. Gastroprotective and antioxidant effects of usnic acid on indomethacininduced gastric ulcer in rats. J Ethnopharmacol. 2006;103:59-65 https://doi. org/10.1016/j.jep.2005.06.043.

49. El-Missiry MA, El-Sayed $\mathrm{IH}$, Othman Al. Protection by metal complexes with SOD-mimetic activity against oxidative gastric injury induced by indomethacin and ethanol in rats. Ann Clin Biochem. 2001;38:694-700 https://doi.org/10.1258/0004563011900911.

50. Graziani G, D'Argenio G, Tuccillo C, Loguercio C, Ritieni A, Morisco F, Del Vecchio BC, Fogliano V, Romano M. Apple polyphenol extracts prevent damage to human gastric epithelial cells in vitro and to rat gastric mucosa in vivo. Gut. 2005:54:193-200 https://doi.org/10.1136/gut.2004.046292.

51. Horiuchi M, Wachi H, Seyama Y. Effects of Bidens pilosa L. var. radiate Scherff on experimental gastric lesion. J Nat Med. 2010;64:430-5 https://doi.org/10. 1007/s1 1418-010-0426-5.

52. Yesilada $\mathrm{E}$, Gurbuz I. Evaluation of the antiulcerogenic activity profile of a flavonol diglucoside from Equisetum palustre L. J Ethnopharmacol. 2010;131: 17-21 https://doi.org/10.1016/j.jep.2010.05.011.

53. Lim J-M, Song C-H, Park S-J, Park D-C, Cho H-R, Jung G-W, Bashir KMI, Ku SK, Choi J-S. Protective effects of a triple-fermented barley extract (FBe) against $\mathrm{HCl} / \mathrm{EtOH}$-induced gastric mucosa damage in mice. Food Sc Nutr. 2018:1-11 https://doi.org/10.1002/fsn3.745.

\section{Ready to submit your research? Choose BMC and benefit from:}

- fast, convenient online submission

- thorough peer review by experienced researchers in your field

- rapid publication on acceptance

- support for research data, including large and complex data types

- gold Open Access which fosters wider collaboration and increased citations

- maximum visibility for your research: over $100 \mathrm{M}$ website views per year

At $\mathrm{BMC}$, research is always in progress.

Learn more biomedcentral.com/submission 